\title{
DISCOVERY OF A 35-METER-THICK, OIL-STAINED SANDSTONE INTERVAL IN OUTCROP OF THE TONNIE SILTSTONE MEMBER, CHINITNA FORMATION, LOWER COOK INLET, SOUTH-CENTRAL ALASKA
}

Trystan M. Herriott and Marwan A. Wartes

\section{Preliminary Interpretive Report 2017-5}

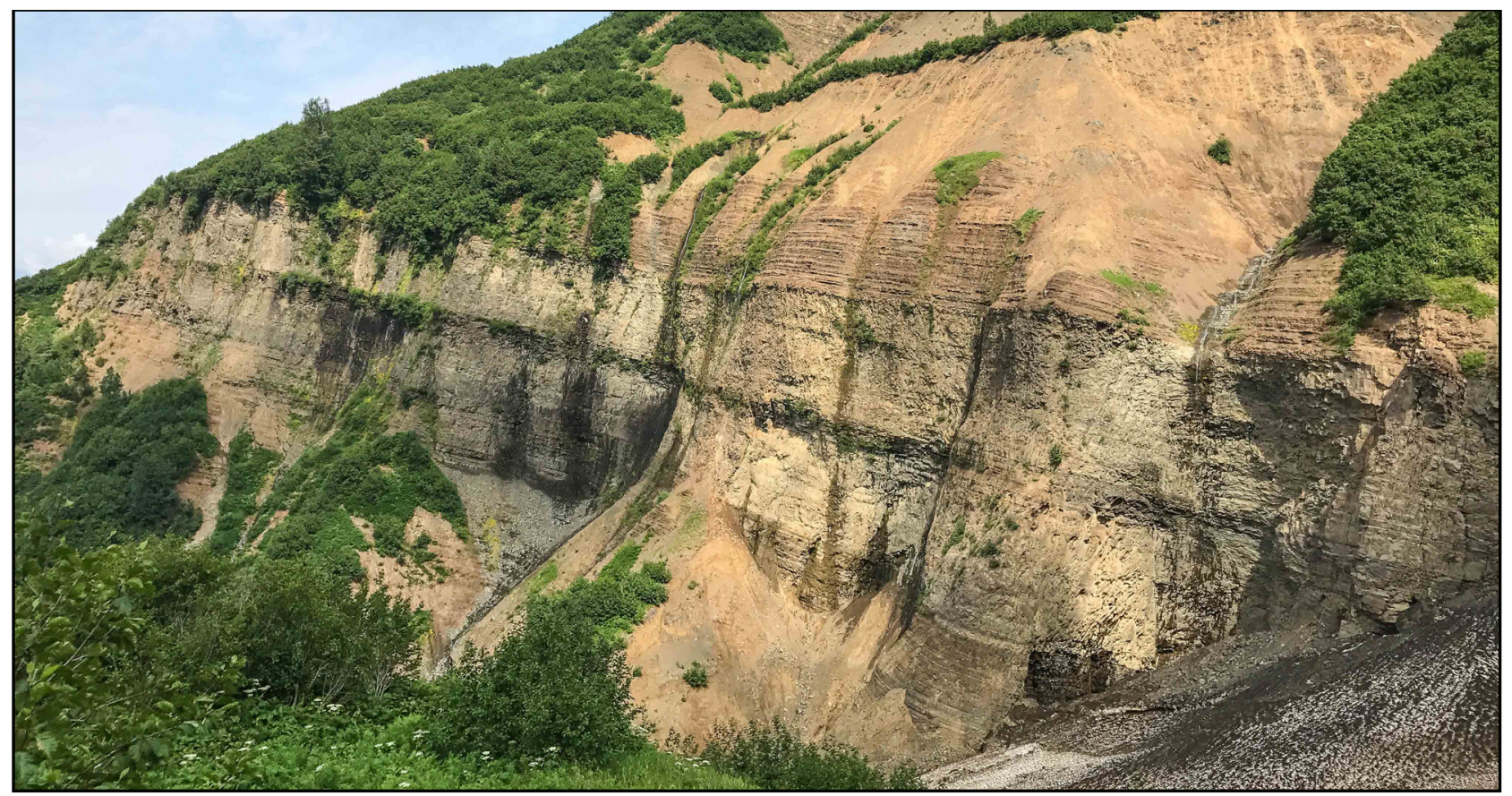

Photograph of an oil-stained sandstone interval in the Tonnie Siltstone Member (Chinitna Formation) at a locality informally referred to as the amphitheater. This interval, which is $\sim 35 \mathrm{~m}$ thick and the focus of this paper, is the cliffforming, light-brown-light-gray-weathering sandstone unit that trends across the center of the photograph. See figures $3-5$ for photogeologic context of this outcrop. Photograph by T.M. Herriott.

This publication is PRELIMINARY in nature and meant to allow rapid release of field observations or initial interpretations of geology or analytical data. It has undergone limited peer review, but does not necessarily conform to DGGS editorial standards. Interpretations or conclusions contained in this publication are subject to change. 
STATE OF ALASKA

Bill Walker, Governor

DEPARTMENT OF NATURAL RESOURCES

Andrew T. Mack, Commissioner

DIVISION OF GEOLOGICAL \& GEOPHYSICAL SURVEYS

Steve Masterman, State Geologist and Director

Publications produced by the Division of Geological \& Geophysical Surveys (DGGS) are available to download from the DGGS website (dggs.alaska.gov). Publications on hard-copy or digital media can be examined or purchased in the Fairbanks office:

\author{
Alaska Division of Geological \& Geophysical Surveys \\ 3354 College Rd., Fairbanks, Alaska 99709-3707 \\ Phone: (907) 451-5010 Fax (907) 451-5050 \\ dggspubs@alaska.gov | dggs.alaska.gov
}

\title{
DGGS publications are also available at:
}

Alaska State Library,

Historical Collections \& Talking Book Center

395 Whittier Street

Juneau, Alaska 99811

Alaska Resource Library and Information Services (ARLIS)

3150 C Street, Suite 100

Anchorage, Alaska 99503

\section{Suggested citation:}

Herriott, T.M., and Wartes, M.A., 2017, Discovery of a 35-meter-thick, oil-stained sandstone interval in outcrop of the Tonnie Siltstone Member, Chinitna Formation, lower Cook Inlet, south-central Alaska: Alaska Division of Geological \& Geophysical Surveys Preliminary Interpretive Report 2017-5, 12 p. http://doi.org/10.14509/29837
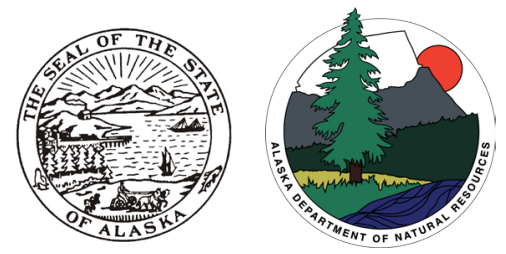


\title{
DISCOVERY OF A 35-METER-THICK, OIL-STAINED SANDSTONE INTERVAL IN OUTCROP OF THE TONNIE SILTSTONE MEMBER, CHINITNA FORMATION, LOWER COOK INLET, SOUTH-CENTRAL ALASKA
}

\author{
Trystan M. Herriott ${ }^{1}$ and Marwan A. Wartes ${ }^{1}$
}

\section{INTRODUCTION}

Recent field studies in the Iniskin-Tuxedni Bays area (fig. 1) were led by the Alaska Division of Geological \& Geophysical Surveys, aiming to further delineate the geologic framework and petroleum systems of Cook Inlet (see Gillis, 2013, 2014; LePain and others, 2013; Wartes, 2015; Herriott, 2016). This work is notably yielding insights regarding base-level cyclicity and timing for export of coarse sediment into the forearc basin, which bears on the distribution of potential Mesozoic-age hydrocarbon reservoirs in Cook Inlet (for example, Herriott and others, 2016, 2017a, $2017 \mathrm{~b}$ ). During the course of these investigations several occurrences of oil-stained outcrops were discovered in Jurassic (Wartes and Herriott, 2014, 2015) and Cretaceous sandstones (LePain and others, 2012; Gillis, 2016), demonstrating that oil migrated into numerous Mesozoic units. Additionally, renewed industry interest in a Jurassic petroleum system on the Iniskin Peninsula builds on more than a century of exploration, and there are indications that modern exploration methods may reveal commercial oil accumulations in the area (Buthman, 2017).

During a geologic mapping traverse of summer 2017 we discovered an oil-stained sandstone interval in the Middle Jurassic Chinitna Formation southwest of Tuxedni Channel (fig. 1). This occurrence of hydrocarbons in the Tonnie Siltstone Member is remarkable for its local ubiquity: sandstone rubble and outcrops of the approximately 35 - $\mathrm{m}$-thick base-of-Tonnie sandstone succession across a lateral extent of at least $250 \mathrm{~m}$ are distinctly petroliferous. The scale of this exposure is at least two orders of magnitude greater in area than any of the previously discovered oil-stained outcrops in the Iniskin-Tuxedni Bays area (see references above). Furthermore, this apparently matrix-hosted oil is significant for an area where petroleum occurrences are commonly associated with fractures (Detterman and Hartsock, 1966; Wartes and Herriott, 2014), and commercial oil production in the basin is nearly entirely limited to the overlying Cenozoic stratigraphy (for example, LePain and others, 2013). This short paper briefly describes the oil-stained Tonnie sandstone and offers a preliminary interpretation of the interval's depositional setting, sequence stratigraphy, and petroleum geology. Ultimately, we suggest that this thick, oil-bearing succession may be a reservoir-scale outcrop analogue for potential Jurassic-sandstone-hosted petroleum accumulations in Cook Inlet.

\section{CHINITNA FORMATION-STRATIGRAPHIC OVERVIEW}

The Chinitna Formation principally comprises fine-grained marine strata that in lower Cook Inlet crop out near the arc-proximal, northwest forearc basin margin between Iniskin and Tuxedni Bays (fig. 1). The formation is typically $700 \mathrm{~m}$ thick and has two members-Tonnie Siltstone and the overlying Paveloff Siltstone-of generally comparable thicknesses (Detterman and Hartsock, 1966; Herriott and Wartes, 2014). Coarse-grained basal successions are documented in each of the

'Alaska Division of Geological \& Geophysical Surveys, 3354 College Rd., Fairbanks, Alaska 99709-3707; trystan.herriott@alaska.gov 


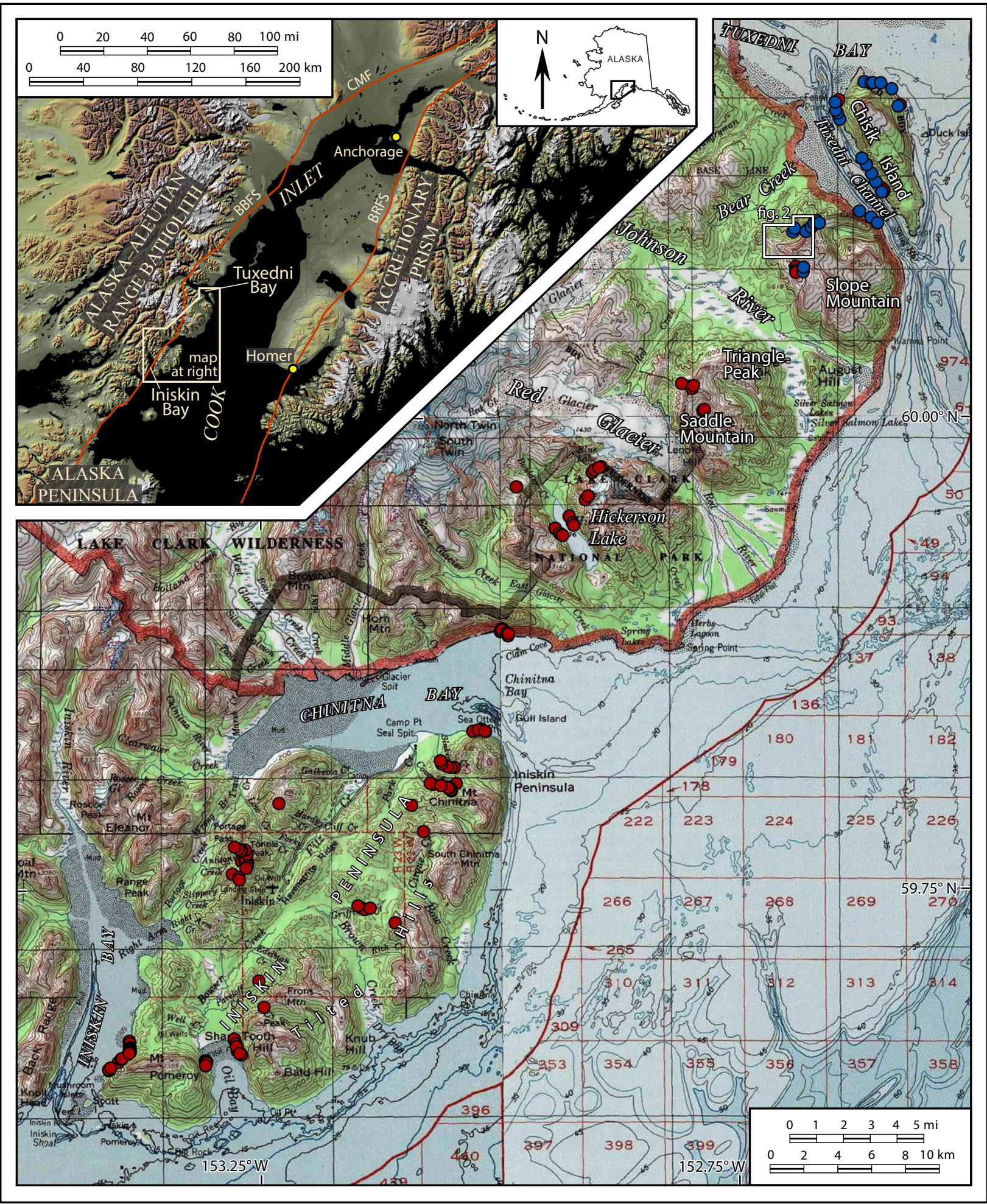

Figure 1. Location map of the Iniskin-Tuxedni Bays area. The authors made detailed observations of the Chinitna Formation at 32 locations during summer 2017 (blue dots) in addition to the 350 locations in the formation that were examined by Herriott and others (2017b) during the preceding six field seasons (red dots). Index map faults (see top-left: BBFS-Bruin Bay fault system; BRFS—Border Ranges fault system; CMF_Castle Mountain fault) are modified from LePain and others (2013; see also references therein). Note the figure 2 geologic map outline between Bear Creek and Slope Mountain. Topographic base map from portions of U.S. Geological Survey Iliamna, Seldovia, Lake Clark, and Kenai 1:250,000-scale quadrangles; shaded-relief image modified from U.S. Geological Survey Elevation Data Set Shaded Relief of Alaska poster. 
members, but these sandstone and conglomerate units are better developed along the ChinitnaTuxedni Bays outcrop trend than they are in the Tilted Hills belt of the Iniskin Peninsula (fig. 1) (see also Detterman and Hartsock, 1966). LePain and others (2013) interpreted the Chinitna Formation as the shelfal record of two transgressive-regressive sedimentation cycles. Subsequent work by Wartes and Herriott (2015) at Chinitna Bay documented probable deltaic strata in the basal Paveloff that is locally oil stained. More recently, Herriott and others $(2016,2017 b)$ suggested that the Chinitna Formation in outcrop chiefly records shallow-marine sedimentation, although observed stratigraphic architectures and sedimentologic evidence indicates that nonmarine and slope strata may occur locally. Furthermore, Herriott and others (2017b) recognized the basal coarse-grained intervals in both members as lowstand systems tracts-each ranging from several tens of meters to more than $100 \mathrm{~m}$ thick - and mapped overlying architectural units as transgressive systems tracts that are each in turn overlain by highstand systems tracts. Ultimately, each Chinitna Formation member was interpreted as a third-order $\left(10^{6}\right.$ years duration) stratigraphic sequence. Note that this paper and related work (Herriott and others, 2016, 2017b) employs subscripted map unit labels to describe and photogeologically map architectural units of the Chinitna, with Jct designating the base-of-Tonnie coarse-grained succession that is described and interpreted below.

Building on these recent advances we examined an extraordinary exposure of Bowser, Chinitna, and Naknek Formations at a locality informally referred to as the amphitheater (figs. 2 and 3). This rock amphitheater is precipitously steep and mainly inaccessible, but aerial reconnaissance yielded lithostratigraphic insights into these units and refined our geologic mapping of the area

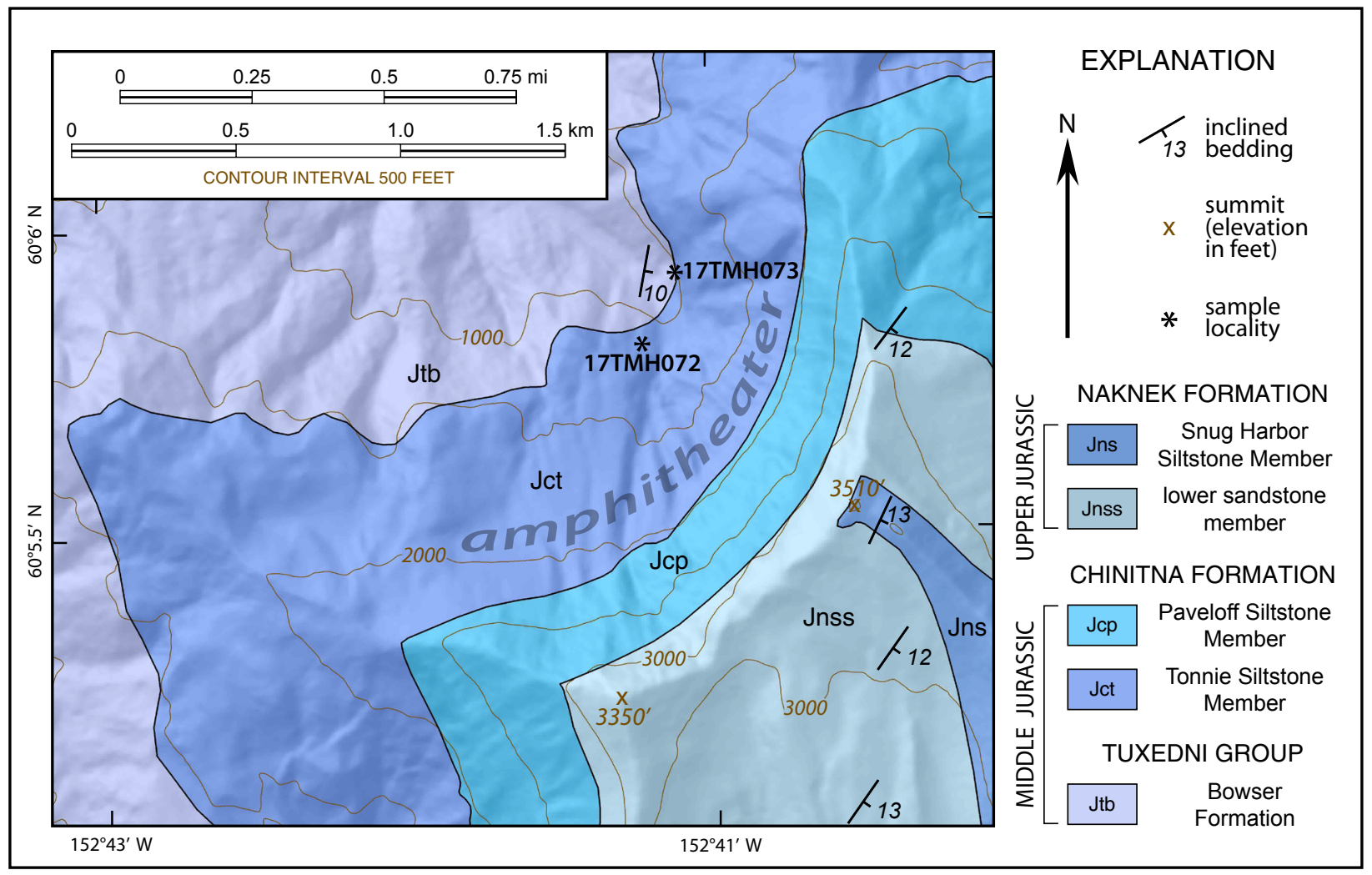

Figure 2. Preliminary geologic map of the amphitheater area. This mapping was completed by the authors in 2017 as part of a larger, Alaska Division of Geological \& Geophysical Surveys-led project to map the geology of the Iniskin-Tuxedni Bays outcrop trend. See figure 1 for index map. Sample location coordinates (WGS84) - 17TMH072: N60.09675 ${ }^{\circ}$ W152.68713 ${ }^{\circ}$; 17TMH073: $\mathrm{N} 60.09868^{\circ} \mathrm{W} 152.68529^{\circ}$. 

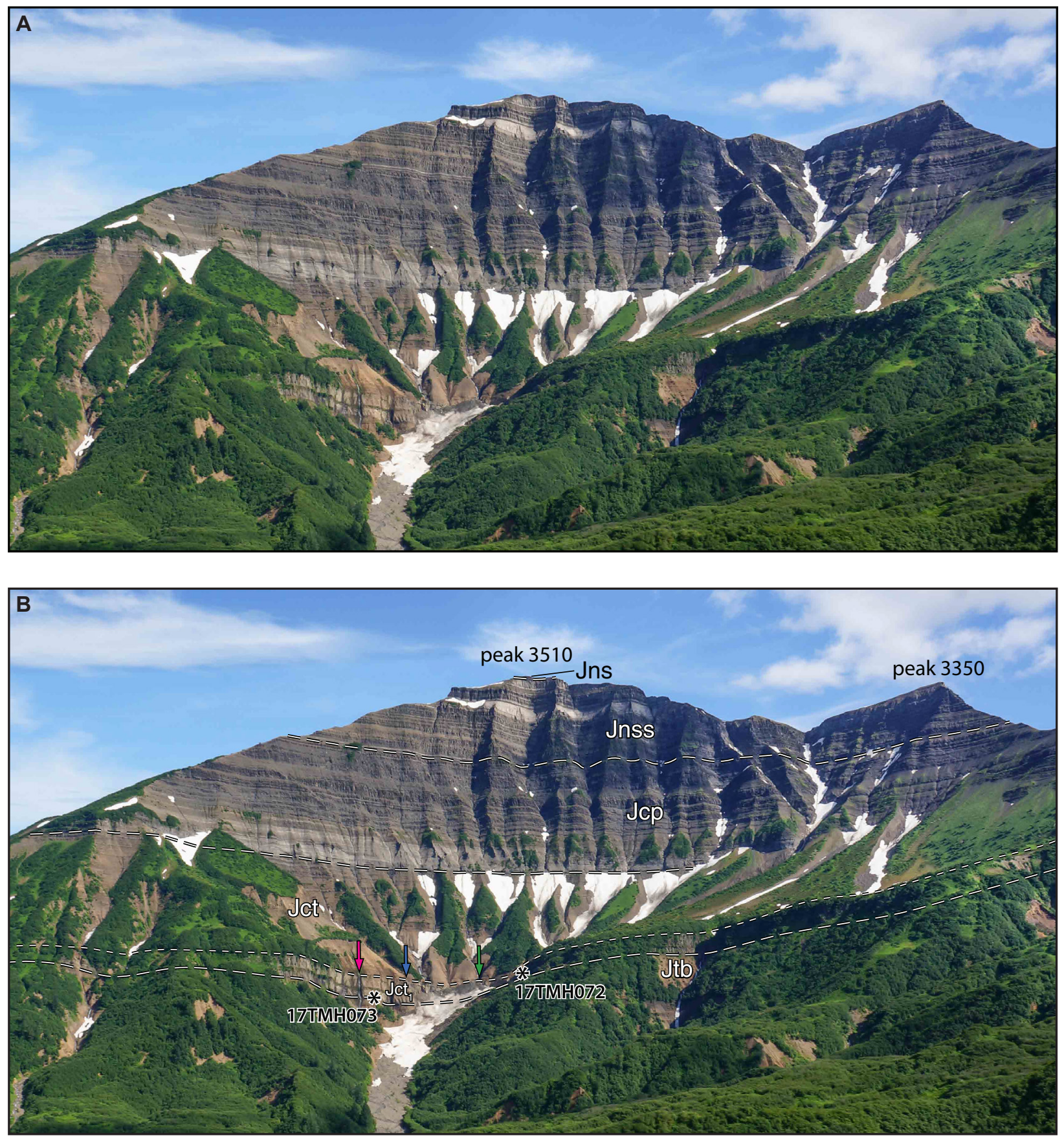

Figure 3. (A) Oblique aerial photograph, with view southeastward of the amphitheater locality. (B) Photogeologic rendition of A. Outcrops and rubble of lower Tonnie Siltstone Member ( $\mathrm{Jct}_{1}$ ) near the head of a snow-filled gully (see area between sample localities 17TMH072 and 17TMH073) are described and interpreted in the text. Approximately $750 \mathrm{~m}$ of topographic relief lie between peak 3510 and 17TMH073 for sense of scale; the amphitheater is $\sim 2 \mathrm{~km}$ wide at the Chinitna-Naknek Formations contact. Colored arrows correspond to the waterfall localities marked on figures 4, 5, and 6A; see also sample localities and peak elevations of figure 2 for additional geographic context. Photograph by M.A. Wartes. Stratigraphic units (ascending order): Jtb-Bowser Formation, Tuxedni Group; Jct _-Tonnie Siltstone Member (basal succession in the sense of Herriott and others, 2017b), Chinitna Formation; Jct-Tonnie Siltstone Member overlying Jct ${ }_{1}$ (correlative to Jct through Jct $_{4}$ of Herriott and others, 2017b), Chinitna Formation; Jcp_-Paveloff Siltstone Member, Chinitna Formation; Jnss_lower sandstone member, Naknek Formation; Jns-Snug Harbor Siltstone Member, Naknek Formation. 
(fig. 2). Additionally, the lower part of the exposure lies at the head of a snow-filled gully (fig. 3), permitting access to the basal sandstone succession of Tonnie that we discovered to be extensively oil stained.

\section{LOWER TONNIE AT THE AMPHITHEATER LOCALITY-OBSERVATIONS}

The Bowser Formation-Tonnie Siltstone Member contact trends across the base of the amphitheater (figs. 2 and 3) and is very well exposed at the head of an unnamed drainage southeast of Bear Creek (fig. 1). This contact is locally sharp, planar, and stratigraphically concordant (fig. 4). The upper part of Bowser consists of a recessive weathering, thinly bedded siltstone and sandstone succession that is overlain by a resistant weathering, thickly bedded sandstone unit of lower Tonnie. The base-of-Tonnie sandstone interval is recognized as Jct $_{1}$ (in the sense of Herriott and others, 2017b), which crops out prominently in nearly vertical cliff faces along the headwall of the snowfilled gully in figure 3 . We completed a foot traverse within this gully, examining Jct ${ }_{1}$ at and between field observation stations 17TMH072 and 17TMH073 (figs. 2 and 3).

\section{Stratigraphic Architecture of Jct ${ }_{1}$}

$\mathrm{Jct}_{1}$ is approximately $35 \mathrm{~m}$ thick and dominantly comprises tabular- and very-thick-bedded, light-brown-light-gray-weathering sandstone (fig. 4). A laterally persistent, tabular- and thinner bedded, dark-gray-brown-weathering, apparently muddy sandstone package occurs near the middle of $\mathrm{Jct}_{1}$, dividing lower Tonnie into the three architectural units of figure 5 . We designate the thinner bedded sandstone package as $\mathrm{Jct}_{1 \mathrm{~B}}(\sim 4 \mathrm{~m}$ thick $)$, which separates a lower Jct ${ }_{1 \mathrm{~A}}$ package $(\sim 13$ $\mathrm{m}$ thick) from an upper Jct ${ }_{1 \mathrm{C}}$ package ( $\sim 18 \mathrm{~m}$ thick) (fig. 5B). The Jct ${ }_{1 \mathrm{~A}}$ and Jct ${ }_{1 \mathrm{C}}$ architectural units typify Jct ${ }_{1}$ and comprise most of the observed facies. Stratal surfaces highlight the mainly tabular-bedded nature for all three of these packages, although some low-relief surfaces occur in Jct ${ }_{1 \mathrm{~A}}$ and $\mathrm{Jct}_{1 \mathrm{C}}$ (more so in the former than the latter). The lateral continuity of bedding is greater in Jct than it is $\mathrm{Jct}_{1 \mathrm{~A}}$, rendering a somewhat more amalgamated, massive-weathering character to Jct ${ }_{1 \mathrm{~A}}$. The top of Jct ${ }_{1}$ is sharply and concordantly overlain by a stratigraphic succession that is thinner bedded, mud prone, and more generally characteristic of regional Tonnie Siltstone Member exposures (see Jct ${ }_{2}$ [in the sense of Herriott and others, 2017b] of figs. 4 and 5).

\section{Lithologic Character, Oil Stain, and Samples of Jct ${ }_{1}$}

$\mathrm{Jct}_{1}$ outcrops are notably difficult to access, but our reconnaissance of $\mathrm{Jct}_{1 \mathrm{~A}}$ and $\mathrm{Jct}_{1 \mathrm{C}}$ at $17 \mathrm{TMH} 073$ and 17TMH072, respectively, suggests that these architectural units are mainly well sorted, texturally structureless, fine-grained sandstone. Rubble of Jct typically forms sub-metersized boulders that expose medium-gray-green-colored sandstone along fresh, arcuate fracture faces (fig. 6). Boulders of this distinct lithology are scattered throughout the snow-filled gully at the base of the amphitheater (fig. 6B). These boulders are ubiquitously petroliferous, including recent $\mathrm{Jct}_{1 \mathrm{C}}$ rockfall at 17TMH072 (fig. 6A), as is outcrop of $\mathrm{Jct}_{1 \mathrm{~A}}$ at 17TMH073 (figs. 4 and 5).

We collected oil-stained sandstone samples at 17TMH072 from rockfall that is unequivocally sourced from Jct ${ }_{1 \mathrm{C}}$ (figs. 2, 3, and 6A). These samples will be analyzed for porosity, permeability, and petrographic composition; the geochemistry of extracted hydrocarbons will be characterized in order to constrain the probable source rock(s). Hand sample examination of the petroliferous samples suggests that the oil is matrix hosted, although petrographic evaluation will further test this preliminary inference. Additionally, we sampled a sandstone bed directly above the Bowser- 

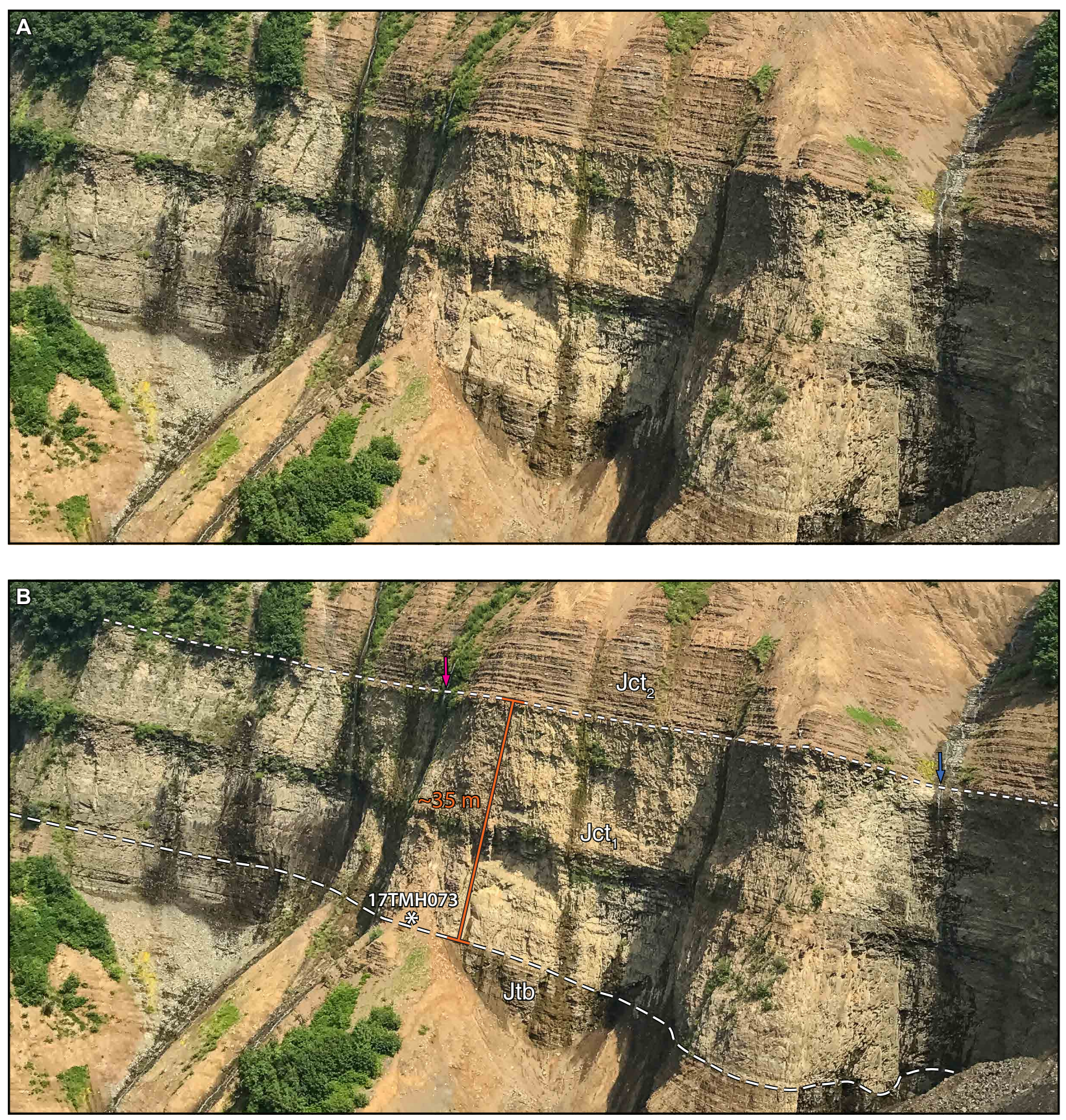

Figure 4. (A) Photographic view northeastward of an exposure near the amphitheater's base immediately northeast of the snow-filled gully in figure 3. (B) Photogeologic rendition of A. Note the chiefly very-thick-bedded and resistant-weathering

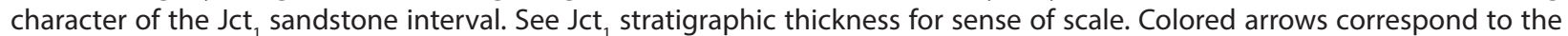
waterfall localities marked on figure 3; see also sample location 17TMH073 on figures 2 and 3 for additional geographic context. Photograph by T.M. Herriott. Stratigraphic units (ascending order): Jtb-Bowser Formation, Tuxedni Group; Jct 1 -Tonnie Siltstone Member (architectural unit in the sense of Herriott and others, 2017b), Chinitna Formation; Jct ${ }_{2}$-Tonnie Siltstone Member (architectural unit in the sense of Herriott and others, 2017b), Chinitna Formation. 

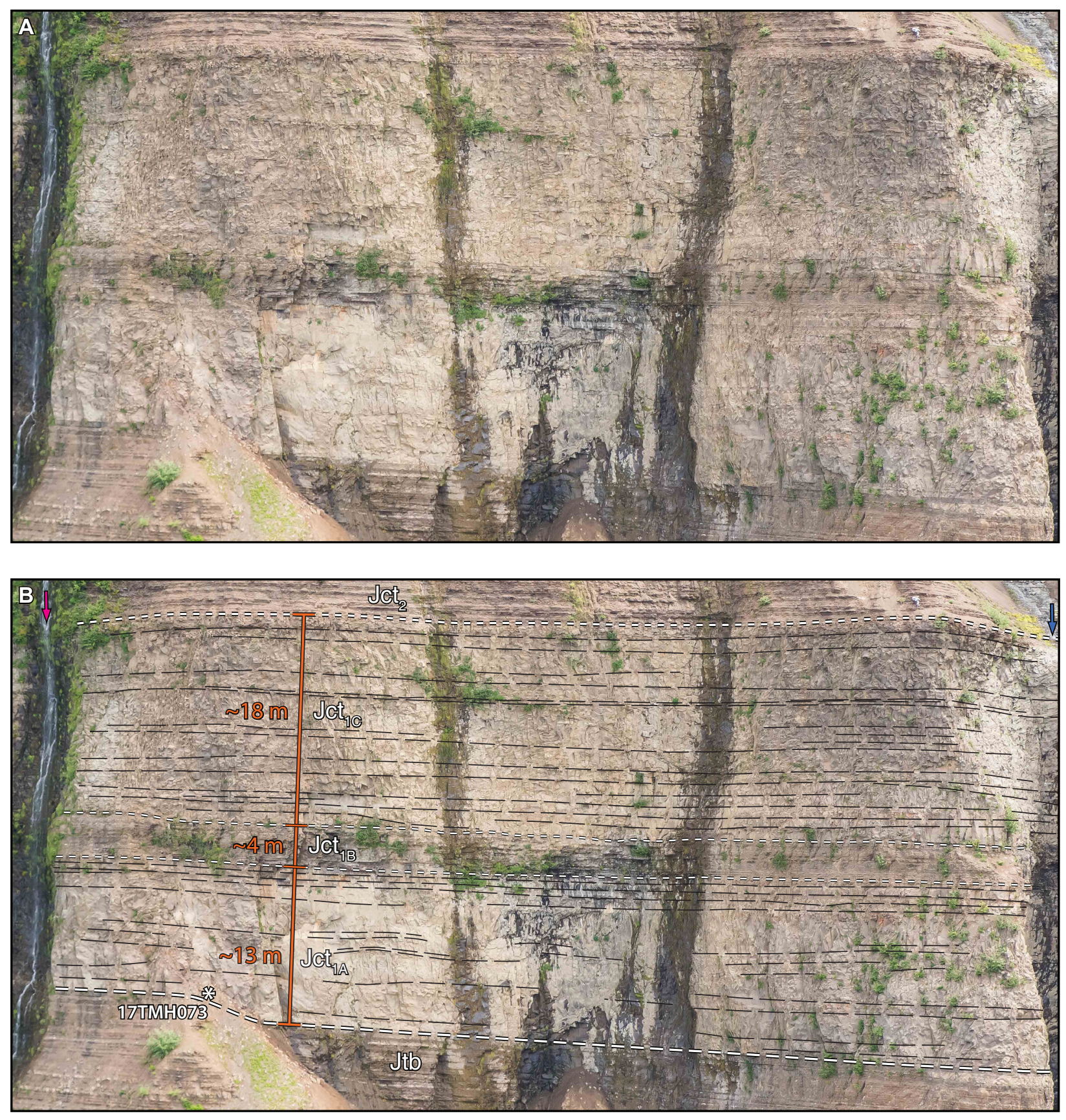

Figure 5. (A) Oblique aerial photograph, with view eastward of the Jct interval. (B) Photogeologic rendition of $A$, highlighting $\mathrm{Jct}_{1}$ architectural units discussed in the text. Thin, long-dashed lines mapped on $\mathrm{Jct}_{1 \mathrm{~A}}$ and $\mathrm{Jct}_{1 \mathrm{C}}$ are stratal surfaces; the lateral continuity of tabular beds in $\mathrm{Jct}_{1 \mathrm{~B}}$ is clearly recognizable without detailed mapping of stratal surfaces. Width of view is $\sim 80 \mathrm{~m}$ for sense of scale. Colored arrows correspond to the waterfall localities marked on figures 3 and 4; see also sample location 17TMH073 on figures 2-4 for additional geographic context. Photograph by T.M. Herriott. See figure 4 for explanation of stratigraphic units. 

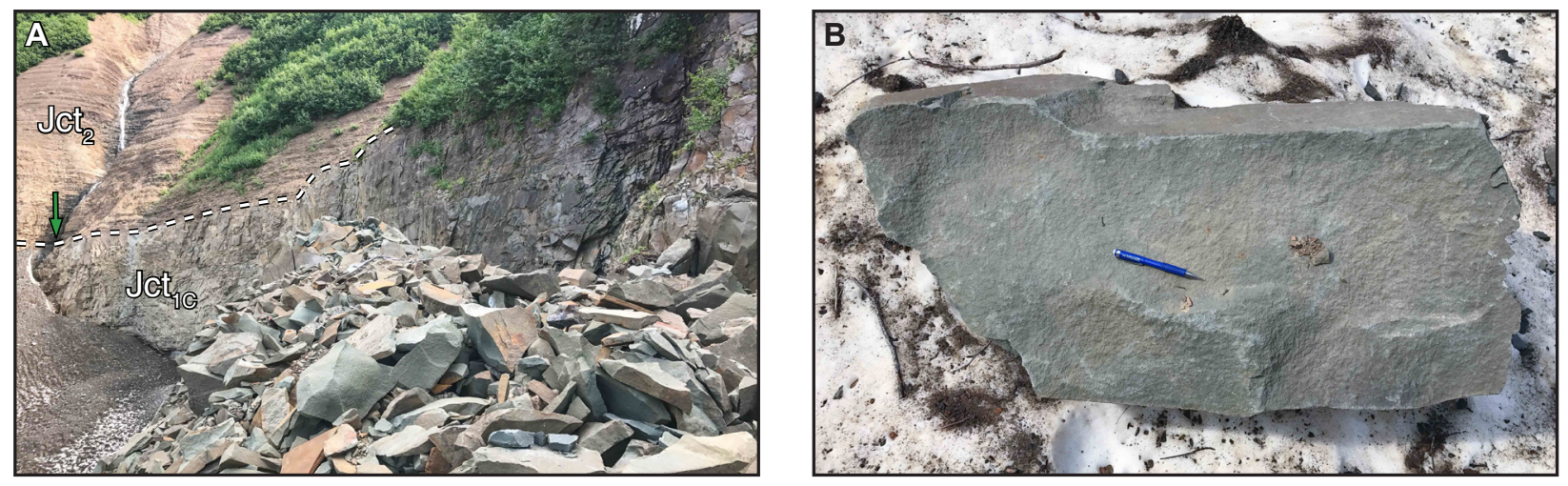

Figure 6. Photographs highlighting the character of Jct rubble. (A) Recent rockfall and outcrop of Jct $_{1 C}$ at sample locality 17TMH072. Jct $_{1 \mathrm{C}}$ visible near the unit label is approximately the total thickness of this package ( 18 $\left.\mathrm{m}\right)$ for sense of scale. Green arrow corresponds to the waterfall locality marked on figure 3. See figures 4 and 5 for explanation of stratigraphic units. (B) Typical example of a Jct, boulder observed within the snow-filled gully of figure 3. Fresh fracture surfaces on these distinct sandstone boulders are usually strongly petroliferous. Pencil is $14 \mathrm{~cm}$ long. Photographs by T.M. Herriott.

Tonnie contact at 17TMH073 (figs. 2-5); this sample is pending analysis for detrital zircon $\mathrm{U}-\mathrm{Pb}$ geochronology to constrain the maximum depositional age for strata that immediately overlie this regionally significant base-of-Tonnie surface (see below).

\section{INTERPRETATIONS AND DISCUSSION}

\section{Sedimentology and Depositional Systems}

Herriott and others (2017b) recognized several prominent exposures of Jct ${ }_{1}$ along the Hickerson Lake-Johnson River trend, as well as on Chisik Island (fig. 1), interpreting the coarse-grained basal Tonnie in the area as probable shallow-marine deposits of shoreline-proximal settings. This regional context, the approximately depositional-strike nature of the Chinitna outcrop belt (compare with discussion by Herriott and others, 2017a), and the lithostratigraphy of Jct of this study indicates that the oil-stained Tonnie interval also probably reflects a shallow-marine depositional environment. Our preliminary sedimentologic characterization of Jct ${ }_{1}$ at the amphitheater as dominantly comprising tabular, very thick, structureless sandstone beds suggests event-bed sedimentation with high instantaneous accumulation rates of well-sorted sand. These observations and process considerations are consistent with laminar to partly turbulent (for example, hyperconcentrated and concentrated density flows: Mulder and Alexander, 2001) and/or chiefly turbulent (for example, hyperpycnal flows: Mulder and Alexander, 2001; Plink-Björklund and Steel, 2004; Bhattacharya, 2006) sediment transport and depositional processes, perhaps in a delta front to proximal prodelta/inner shelf environment subjected to sand-rich, high energy, punctuated sediment gravity flows. The amalgamated character of Jct ${ }_{1 \mathrm{~A}}$ and $\mathrm{Jct}_{1 \mathrm{C}}$ may indicate that waxing energy in turbulent sediment gravity flow fronts removed heterolithic, waning-flow deposits of the underlying event bed; in this scenario, the bulk of Jct ${ }_{1}$ may in fact record laminar to dampened turbulence flow conditions as noted above. Subordinate, low-relief stratal surfaces of figure 5B potentially reflect wide aspect ratio channels that were formed by more erosive, principally turbulent sediment gravity flows that traversed the paleo-seafloor. Additional documentation of grading and sedimentary structures (for example, climbing ripples) - including any preserved heterolithic bed tops-are keys to further elucidating the process-response nature of these sedimentation units and bolstering the depositional-systems framework of Jct ${ }_{1}$ at the amphitheater. 


\section{Sequence-Stratigraphic and Petroleum-Geologic Context}

The Bowser-Tonnie contact is interpreted as a sequence-bounding basal surface of forced regression (see Herriott and others, 2017b), with Jct ${ }_{1}$ being a lowstand systems tract (LST) with probable deltaic associations in outcrop. The thinly bedded, mud-prone, marine-fossil-rich upper Bowser (compare with Detterman and Hartsock, 1966; LePain and others, 2013) is consistent with highstand systems tract (HST) sedimentation in a more distal-probably shelfal—setting than the overlying, shoreline-proximal Jct ${ }_{1}$. General concepts of shallow-marine base-level cyclicity (for example, Catuneanu and others, 2009) and our lithostratigraphic observations of these units support this interpretation of the upper Bowser to lower Tonnie transition (discussed further below). The $\mathrm{Jct}_{1 \mathrm{~B}}$ package at the amphitheater locality may record autocyclic processes in up-dip elements of deltaic depositional systems or a higher frequency base-level cycle within the third-order LST of $\mathrm{Jct}_{1}$. The Jct $-\mathrm{Jct}_{2}$ contact is interpreted as a transgressive surface, with overlying Jct ${ }_{2}$ constituting a transgressive systems tract (TST) that reflects waning prodelta/shelfal sedimentation during flooding of the regressive depositional systems of the Jct ${ }_{1}$ LST (Herriott and others, 2017b).

This preliminary report adds to a growing catalog of matrix-hosted residual oil documented in Mesozoic sandstones of the Iniskin-Tuxedni Bays area (LePain and others, 2012; Gillis, 2016), including an occurrence in a comparable coarse-grained succession at the base of Paveloff Siltstone Member (Wartes and Herriott, 2015; Herriott and others, 2017b). Jct ${ }_{1}$ at the amphitheater is currently the northernmost oil-stained outcrop reported in the area. Furthermore, perhaps the most remarkable aspect of the Jct ${ }_{1}$ oil stain of this study is its apparent areal extent. Jct in outcrop, recent rockfall, and boulders strewn across the snow-filled gully are seemingly universally petroliferous, suggesting that this unit was, at a minimum, pervasively charged with oil between the two sample localities of figure 3 . These constraints preliminarily delineate an oil-stained interval that is approximately $35 \mathrm{~m}$ thick and persists across an at least 250-m-wide lateral extent.

Work by Detterman and Hartsock (1966) provides regional structural context for the amphitheater locality, with their dip-parallel, C-C' cross section extending from the Jurassic arc batholith in the northwest, through the amphitheater locality, and to the Cook Inlet coast in the southeast. The Lower Jurassic arc (Talkeetna Formation) through Middle and Upper Jurassic forearc (Tuxedni Group and Chinitna and Naknek Formations) stratigraphy along this cross section constitutes a relatively uniform, gently basinward/southeastward-dipping panel with several steeply dipping cross faults but no large anticlinal closures. Note also that we did not encounter oil-stained Bowser strata in the area, and $\mathrm{Jct}_{2}$ also seems unlikely to be oil stained due to its mud-prone character. Thus, outcrop evidence suggests that reservoir potential in the upper Bowser and Jct ${ }_{2}$ are probably negligible, but is it likely that these HST (upper Bowser) and TST $\left(\mathrm{Jct}_{2}\right)$ deposits served as hydrocarbon seals? The structural and stratigraphic context suggests that such a case is permissible, and that a stratigraphic trap should be considered with respect to the oil accumulation that is now exhumed at the amphitheater. One plausible scenario for stratigraphically trapping oil in the Tonnie sandstone of this study is presented in figure 7, where the up-dip extent of the Jct ${ }_{1}$ LST-which prograded over the upper Bowser HST-is onlapped by the Jct ${ }_{2}$ TST. In other words, oil-stained Jct may be a sandy, wedge-shaped, sequence-stratigraphic architectural unit that is enveloped by muddy deposits of systems tracts recorded by upper Bowser and $\mathrm{Jct}_{2}$. This overall stacking architecture, if correctly interpreted, is potentially capable of trapping hydrocarbons in the gently basinward-dipping panel of Jurassic stratigraphy, although the upper Bowser and Jct ${ }_{2}$ seal elements of figure 7 are not proven. 


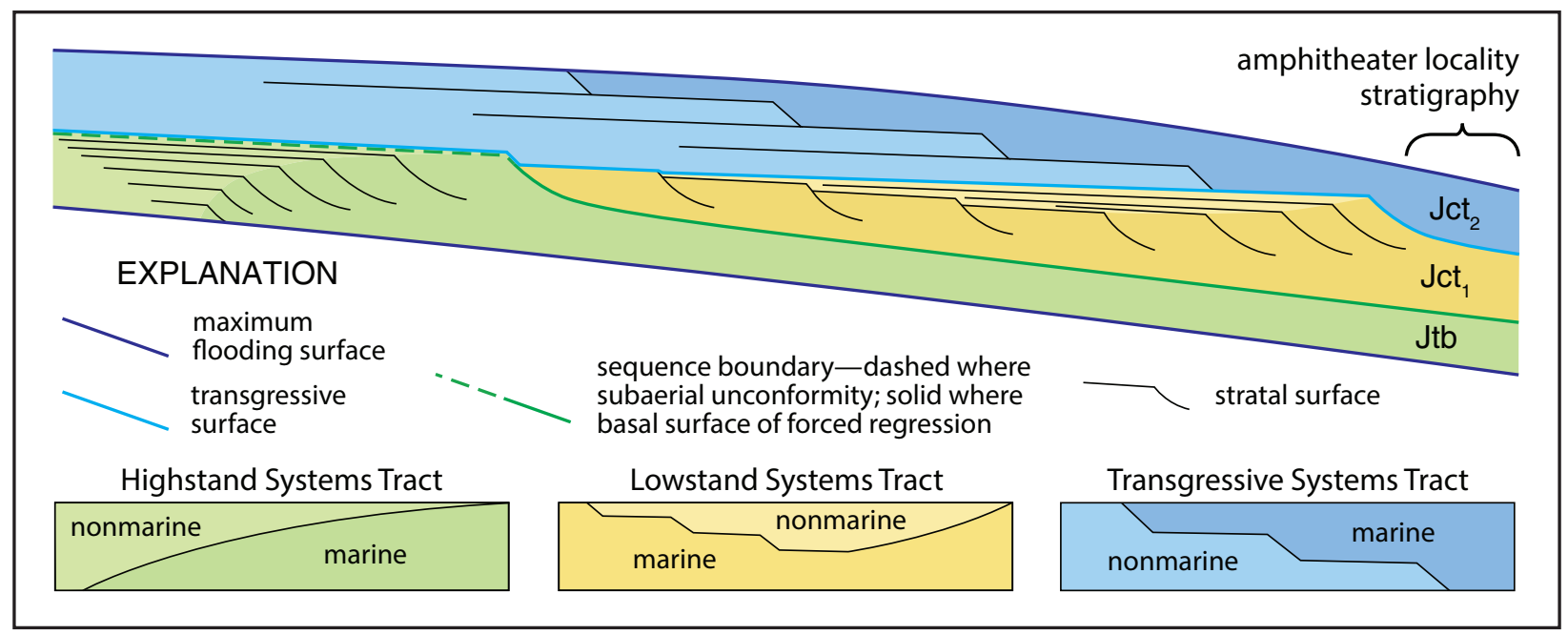

Figure 7. Schematic line drawing of sequence-stratigraphic architecture in downstream-controlled, nonmarine through shelfal

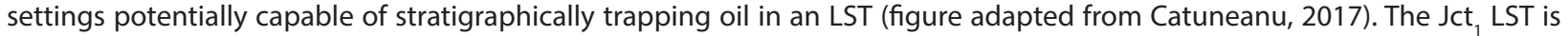
chiefly thickly bedded and sand rich. The Jtb HST and Jct 2 TST are principally thinly bedded and mud prone, serving as trapping elements in this scenario (see text for further discussion); note that the lower part of Bowser and upper part of Tonnie are not included in this figure. Note also that the sequence-stratigraphic framework outlined here and by Herriott and others (2017b) does not uniquely solve for this figure's stacking pattern (see discussion by Catuneanu, 2017) but it is a viable hypothesis based on available stratigraphic evidence.

$\mathrm{Jct}_{1}$ clearly reflects an episode of forearc sedimentation where coarse detritus was exported into the basin during early Chinitna time. Deep-water, down-dip equivalents to Jct ${ }_{1}$ may also have been charged with oil and today remain in the Cook Inlet subsurface. Pending analyses of samples collected in the course of this study will characterize extracted hydrocarbons and reservoir parameters of the host strata. Additionally, the detrital zircon sample collected from directly above the base-of-Chinitna sequence boundary will yield the first geochronologic age constraints for Tonnie, potentially providing a chronostratigraphic tie for outcrop to subsurface correlations. More broadly, our reconnaissance of Jct ${ }_{1}$ at the amphitheater locality indicates that this exposure is a candidate outcrop analogue for an oil-field-scale, sandstone-hosted, potentially stratigraphically trapped hydrocarbon accumulation in the Jurassic stratigraphy of Cook Inlet.

\section{ACKNOWLEDGMENTS}

The State of Alaska provided primary funding for this study. The U.S. Geological Survey's National Cooperative Geologic Mapping Program (NCGMP) supported geologic mapping in 2017 through STATEMAP (award number G17AC00211). Land access for Chinitna Formation and associated studies was permitted by Cook Inlet Region, Inc. (CIRI), and Chickaloon, Knik, Ninilchik, Salamatof, Seldovia, and Tyonek village corporations, as well as Lake Clark National Park \& Preserve. Helicopter pilot Mike Brandau safely transported our field crew during the 2017 field season. The owners and staff of the former cannery on Chisik Island are thanked for their hospitality. John Barefoot digitized the geology of figure 2 .

Bob Gillis led numerous geologic mapping campaigns in the area that proved fundamental to further understanding the Chinitna Formation. We thank Rick Stanley, Paul Decker, Ken Helmold, and Nina Harun for their contributions to the regional Chinitna Formation studies. This work benefitted from many fruitful stratigraphic discussions with Dave LePain, who also provided a manuscript review that improved this paper. 


\section{REFERENCES CITED}

Bhattacharya, J.P., 2006, Deltas, in Posamentier, H.W., and Walker, R.G., eds., Facies Models Revisited: SEPM (Society for Sedimentary Geology) Special Publication 84, p. 237-292.

Buthman, D.B., 2017, Iniskin Peninsula conventional and unconventional exploration targets, Jurassic Tuxedni Group, lower Cook Inlet onshore, Alaska: American Association of Petroleum Geologists, Pacific Section Annual Meeting, Anchorage, Alaska, 23 May 2017, Program and Abstracts p. $54-55$.

Catuneanu, Octavian, 2017, Sequence stratigraphy: Guidelines for a standard methodology, in Montenari, Michael, ed., Stratigraphy \& Timescales, Advances in Sequence Stratigraphy, Volume 2: Academic Press, Chapter 1, p. 1-57. https://doi.org/10.1016/bs.sats.2017.07.003

Catuneanu, Octavian, Abreu, V., Bhattacharya, J.P., Blum, M.D., Dalrymple, R.W., Eriksson, P.G., Fielding, C.R., Fisher, W.L., Galloway, W.E., Gibling, M.R., Giles, K.A., Holbrook, J.M., Jordan, R., Kendall, C.G.St.C., Macurda, B., Martinsen, O.J., Miall, A.D., Neal, J.E., Nummedal, Dag, Pomar, L., Posamentier, H.W., Pratt, B.R., Sarg, J.F., Shanley, K.W., Steel, R.J., Strasser, A., Tucker, M.E. and Winker, C., 2009, Towards the standardization of sequence stratigraphy: Earth-Science Reviews, v. 92, no. 1-2, p. 1-33. http://doi.org/10.1016/j.earscirev.2008.10.003

Detterman, R.L., and Hartsock, J.K., 1966, Geology of the Iniskin-Tuxedni region, Alaska: U.S. Geological Survey Professional Paper 512, 78 p., 6 sheets, scale 1:63,360. https://pubs.er.usgs. gov/publication/pp512

Gillis, R.J., ed., 2013, Overview of 2012 field studies-Upper Alaska Peninsula and west side of lower Cook Inlet, Alaska: Alaska Division of Geological \& Geophysical Surveys Preliminary Interpretive Report 2013-1, 48 p. http://doi.org/10.14509/24824

Gillis, R.J., ed., 2014, Cook Inlet program 2013 field studies-Observations and preliminary interpretations from new 1:63,360-scale geologic mapping of the Iniskin Peninsula, lower Cook Inlet, Alaska: Alaska Division of Geological \& Geophysical Surveys Preliminary Interpretive Report 2014-2, 31 p. http://doi.org/10.14509/27303

Gillis, R.J., 2016, Discovery of a new sandstone with residual oil in Maastrichtian(?) strata at Shelter Creek, lower Cook Inlet, Alaska, in Herriott, T.M., ed., Petroleum-related geologic studies in lower Cook Inlet during 2015, Iniski-Tuxedni region, south-central Alaska: Alaska Division of Geological \& Geophysical Surveys Preliminary Interpretive Report 2016-1-7, p. 51-58. http:// doi.org/10.14509/29541

Herriott, T.M., ed., 2016, Petroleum-related geologic studies in lower Cook Inlet during 2015, Iniskin-Tuxedni region, south-central Alaska: Alaska Division of Geological \& Geophysical Surveys Preliminary Interpretive Report 2016-1, 78 p. http://doi.org/10.14509/29532

Herriott, T.M., and Wartes, M.A., 2014, Geologic mapping-based observations of the Middle Jurassic Chinitna Formation and Upper Jurassic Naknek Formation in the Tilted Hills, Iniskin Peninsula, Cook Inlet, Alaska: Alaska Division of Geological \& Geophysical Surveys Preliminary Interpretive Report 2014-3, 23 p. http://doi.org/10.14509/27305

Herriott, T.M., Wartes, M.A., and Decker, P.L., 2017a, Deep-water canyons and sequence-stratigraphic framework of the Upper Jurassic Naknek Formation, Cook Inlet forearc basin, south-central Alaska: Alaska Division of Geological \& Geophysical Surveys Report of Investigation 20174, 53 p. http://doi.org/10.14509/29707 
Herriott, T.M., Wartes, M.A., Decker, P.L., and Harun, N.T., 2016, Preliminary stratigraphic architecture of the Middle Jurassic Paveloff Siltstone Member, Chinitna Formation, Tuxedni Bay area, Cook Inlet, Alaska, in Herriott, T.M., ed., Petroleum-related geologic studies in lower Cook Inlet during 2015, Iniskin-Tuxedni region, south-central Alaska: Alaska Division of Geological \& Geophysical Surveys Preliminary Interpretive Report 2016-1-5, p. 39-44. http://doi. org/10.14509/29539

Herriott, T.M., Wartes, M.A., Stanley, R.G., Decker, P.L., Helmold, K.P., and Harun, N.T., 2017b, Stratigraphy and sedimentology of the Chinitna Formation, Iniskin-Tuxedni Bays area, south-central Alaska-Late Middle Jurassic depositional systems and petroleum prospectivity in Cook Inlet forearc basin (poster): American Association of Petroleum Geologists, Pacific Section Annual Meeting, Anchorage, Alaska, 22-24 May 2017: Alaska Division of Geological \& Geophysical Surveys, 1 sheet. http://doi.org/10.14509/29757

LePain, D.L., Lillis, P.G., Helmold, K.P., and Stanley, R.G., 2012, Migrated hydrocarbons in exposure of Maastrichtian nonmarine strata near Saddle Mountain, lower Cook Inlet, Alaska: Alaska Division of Geological \& Geophysical Surveys Report of Investigation 2012-1, 13 p. http://doi. org/10.14509/23943

LePain, D.L., Stanley, R.G., Helmold, K.P., and Shellenbaum, D.P., 2013, Geologic framework and petroleum systems of Cook Inlet basin, south-central Alaska, in Stone, D.M., and Hite, D.M., eds., Oil and Gas Fields of the Cook Inlet Basin: American Association of Petroleum Geologists Memoir 104, p. 37-116.

Mulder, Thierry, and Alexander, Jan, 2001, The physical character of subaqueous sedimentary density flows and their deposits: Sedimentology, v. 48, p. 269-299. http://doi.org/10.1046/j.13653091.2001.00360.x

Plink-Björklund, Piret, and Steel, R.J., 2004, Initiation of turbidity currents: Outcrop evidence for Eocene hyperpycnal flow turbidites: Sedimentary Geology, v. 165, no. 1, p. 29-52. http://doi. org/10.1016/j.sedgeo.2003.10.013

Wartes, M.A., ed., 2015, Energy-related studies during the 2014 field season, western Cook Inlet, Alaska: Alaska Division of Geological \& Geophysical Surveys Preliminary Interpretive Report 2015-5, 62 p. http://doi.org/10.14509/29455

Wartes, M.A., and Herriott, T.M., 2014, A new occurrence of oil-stained rocks within a small fault zone involving the Middle Jurassic Cynthia Falls Formation, Tuxedni Group, northern Iniskin Peninsula, in Gillis, R.J., ed., Cook Inlet program 2013 field studies-Observations and preliminary interpretations from new 1:63,360-scale geologic mapping of the Iniskin Peninsula, lower Cook Inlet, Alaska: Alaska Division of Geological \& Geophysical Surveys Preliminary Interpretive Report 2014-2-5, p. 23-27. http://doi.org/10.14509/27310

Wartes, M.A., and Herriott, T.M., 2015, Oil-stained sandstone in the Middle Jurassic lower Paveloff Siltstone Member of the Chinitna Formation-Exploring the potential role of facies variations in controlling diagenesis and reservoir quality in western Cook Inlet, Alaska: Alaska Division of Geological \& Geophysical Surveys Preliminary Interpretive Report 2015-7, 9 p. http://doi. org/10.14509/29533 